Nippon Suisan Gakkaishi $\quad 77(1), 53-60$ (2011)

\title{
イカ釣り操業時に船上灯光により形成される船底下陰影部の スルメイカの誘集・釣獲過程にお打る役割
}

四方崇文, $1 *$ 島 敏明, 1 稲田博史, ${ }^{2}$ 三浦郁男, 3

臺田 望, 4 貞安一廣, $5 \mathrm{a}$ 渡部 俊 広 ${ }^{5}$

$(2010$ 年 8 月 18 日受付, 2010 年 10 月 12 日受理)

1石川県水産総合センター, 2 東京海洋大学海洋科学部, 3古野電気株式会社, ${ }^{4}$ 株式会社拓洋理研, 5独水産総合研究センター水産工学研究所

Role of shaded area under squid jigging boat formed by shipboard fishing light in the processes of gathering and capturing Japanese common squid, Todarodes pacificus

\section{TAKAFUmI SHIKATA, ${ }^{*}$ TOSHIAKI SHIMA, ${ }^{1}$ HIROSHI INADA, ${ }^{2}$ IKUO MIURA, ${ }^{3}$ NOZOMU DAIDA, ${ }^{4}$ KAZUHIRo SADAYASU ${ }^{5 a}$ AND TOSHIHIRo WATANABE ${ }^{5}$}

\begin{abstract}
${ }^{1}$ Ishikawa Prefecture Fisheries Research Center, Housu, Ishikawa 927-0435, ${ }^{2}$ Faculty of Marine Science, Tokyo University of Marine Science and Technology, Minato, Tokyo 108-8477, ${ }^{3}$ Furuno Electric Co., Ltd., Chiyoda, Tokyo 101-0024, ${ }^{4}$ Takuyo Co., Ltd., Maizuru, Fukuoka 810-0073, ${ }^{5}$ National Research Institute of Fisheries Engineering, Fisheries Research Agency, Kamisu, Ibaraki 314-0408, Japan
\end{abstract}

The behavior of Japanese common squid Todarodes pacificus under a squid jigging boat (research vessel Hakusan-maru, 167 gross tons) was investigated with echosounder and sonar during jigging operations in the Sea of Japan. Shipboard metal halide lamps $(234 \mathrm{~kW})$ were lit at night, and operations were conducted until enough squid had been gathered. Thereafter, an underwater light emitting diode lamp (600 W) was set under the boat and turned on/off. A shaded area was formed under the boat by the light of shipboard lamps, but it was partially eliminated and deformed by the light of the underwater lamp. Many squid were in the shaded area before the underwater lamp was turned on, but almost all the squid located near and above the lamp moved away from the area immediately after the lamp was turned on. Catch per unit effort (CPUE) decreased markedly while the underwater lamp was lit. Thereafter, when the underwater lamp was turned off, the squid immediately gathered in the shade area and CPUE also increased. These results indicate that the shaded area formed by the light of shipboard lamps gathers the squid under the jigging boat and helps to capture them.

キーワード : スルメイカ, イカ釣り, 漁灯, 船上灯, 水中灯, 行動制御機能, 魚群探知機, ソナー

戦前のイカ釣り漁業では主に石油灯やアセチレン灯が 漁業用光源（漁灯）として用いられた。1) 戦後, スルメ イカに対する高い需要と豊富な資源に支えられて, 漁船 の大型化と動力化, 自動イ力釣機や冷凍機の導入など重 装備化が進み, 船上漁灯（船上灯）についても白熱灯, ハロゲン灯, メタルハライド灯 $(\mathrm{MH}$ 灯)へとその時代 の最先端の照明技術が導入されてきた。1)しかし，イカ 釣り漁船間の漁獲競争のなかで大光量化が進み, 当初数
キロワットであった船上灯の消費電力は 1990 年頃には $300 \mathrm{~kW}$ を超えるまでに増大した。1,2) 現在, 大光量化の 抑止という観点から, 船上灯の消費電力は小型イカ釣り 漁船で $180 \mathrm{~kW}$, 中型イカ釣り漁船で $250 \mathrm{~kW}$ に規制さ れているが, それでも消費電力は極めて多く, 発電に要 する燃油も膨大であり, 中型イカ釣り漁船では年間の燃 油消費量は約 $500 \mathrm{~kL}$ にも達している。3)このような技 術展開を経た結果, イカ釣り漁業では燃油コストが増大

* TEL : 81-768-62-1324. FAX : 81-768-62-4324. Email : shikata@pref.ishikawa.lg.jp

a 現所属: 独水産総合研究センター開発調査センター (Marine Fisheries Research and Development Center, Fisheries Research Agency, Yokohama, Kanagawa 220-6115, Japan) 
し，このことが経営を圧迫する大きな要因になっている。

以上の経緯に加えて，2003 年以降，燃油価格は世界 的に上昇する傾向にあり，地球温暖化対策として二酸化 炭素の排出を抑制する必要性も増している。このため, イカ釣り漁業では発光ダイオード (LED: Light Emitting Diode）を用いた船上灯が省エネルギー技術として 注目され，その実用化研究が活発に進められている。,5) 現在の LED 船上灯については, 点灯時における船体周 囲の海中照度は $\mathrm{MH}$ 船上灯に匹敵する水準に達してい るが，漁獲性能は MH 船上灯に比べてやや低い水準に 留まっており，その実用化には配光の適正化などの技術 改善が必要になっている。6,7) しかし，スルメイカの誘集 や釣獲に㧈いて船上灯光がぞのように機能しているのか 未だ不明な点が多く，技術改善の方向性が見いだせない 状況にある。このような現状を受けて，現在，著者らは イカ釣り漁業に打ける灯光の機能を明らかにするための 研究を進めている。夜間のイカ釣り操業では，船上灯光 により形成される船底下の陰影部がスルメイカの集群や 釣獲に重要であると考えられているが, 8-10)このことを 実証的に示した研究はない。そこで本研究では，船底下 陰影部の機能を明らかにすることを目的として，船上灯 によるイカ釣り操業時に船底下に垂下した水中灯を点灯 ・消灯して，陰影部を消失・出現させ，この時のスルメ イカの行動を魚群探知機とソナーを用いて観察した。本 調査では, 船底下の光環境を水中灯で制御する必要があ り，瞬間点灯や明るさの調節が可能な LED 水中灯を使 用した。その結果，スルメイカの行動が音響機器によっ て明瞭に観察でき, 船底下陰影部の機能を知る手掛りが 得られたので報告する。

\section{材料および方法}

釣獲試験 本調査には石川県水産総合センターの漁業 調查指導船白山丸（総トン数 167 トン）を用いた。白 山丸にはイカ釣り用の $3 \mathrm{~kW}$ 型白色 $\mathrm{MH}$ 船上灯が 78 灯 装備されて抢り，これに株式会社拓洋理研製の $600 \mathrm{~W}$ 型青緑色 LED 水中灯 $(\mathrm{LW}-600 \mathrm{C})$ と $5 \mathrm{~kW}$ 型白色 $\mathrm{MH}$ 水中灯（MTW-50W）をそれぞれ船首と船尾に追 加装備した（Fig. 1)。2008 年と 2009 年の 8〜10月に 日本海中央部の大和堆付近の海域でイカ釣り操業を行っ た。それらの操業のうち本報では Table 1 の操業で得た 結果をまとめた。操業前にシーアンカーを投入し，日没 後から日出前の夜間に $\mathrm{MH}$ 船上灯を全灯点灯し，釣具 ラインに $110 \mathrm{~cm}$ 間隔で擬慨針 24 本を連結した自動イ 力釣機 14 台を稼働させ，釣具ライン下端の釷の垂下深 度を $75 \mathrm{~m}$ に設定して操業した。操業中には 1 時間単位 で釣獲尾数を計数し，釣機 1 台 1 時間当たりの釣獲尾 数（CPUE）を算出した。

海中分光照度分布 2008 年 11 月 12 日の夜間に石川

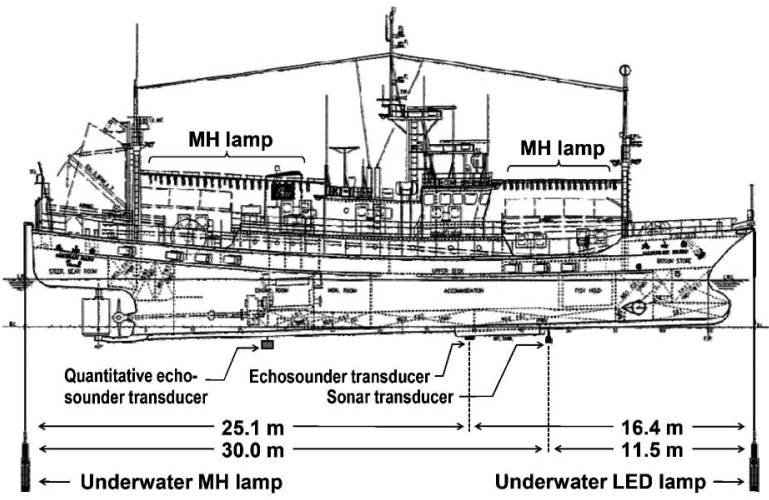

Fig. 1 Arrangement of shipboard metal halide (MH) lamps, underwater lamps and acoustic transducers in R/V Hakusan-Maru.

Table 1 Records of squid jigging operations in this report

\begin{tabular}{|c|c|c|c|c|}
\hline \multirow{2}{*}{ Date*1 } & \multicolumn{2}{|c|}{ Location } & \multirow{2}{*}{$\begin{array}{l}\text { No. of } \\
\text { squid } \\
\text { caught }\end{array}$} & \multirow{2}{*}{$\mathrm{CPUE}^{* 2}$} \\
\hline & Lat. & Lon. & & \\
\hline Sep. 19, 2008 & $\mathrm{~N} 39^{\circ} 23^{\prime}$ & $\mathrm{E} 135^{\circ} 20^{\prime}$ & 5,639 & 53.7 \\
\hline Aug. 21, 2009 & $\mathrm{~N} 40^{\circ} 34^{\prime}$ & E $136^{\circ} 07^{\prime}$ & 7,902 & 132.8 \\
\hline Aug. 22, 2009 & $\mathrm{~N} 40^{\circ} 12^{\prime}$ & $\mathrm{E} 135^{\circ} 23^{\prime}$ & 8,304 & 106.6 \\
\hline Oct. 16,2009 & $\mathrm{~N} 39^{\circ} 50^{\prime}$ & E $134^{\circ} 42^{\prime}$ & 6,593 & 53.8 \\
\hline Oct. 20,2009 & $\mathrm{~N} 39^{\circ} 43^{\prime}$ & $\mathrm{E} 135^{\circ} 02^{\prime}$ & 6,936 & 39.6 \\
\hline
\end{tabular}

*1 Each operation was conducted between sunset and sunrise of the next day.

*2 Catch per unit effort (number of squid caught/machine-hour).

県能登町沖 $\left(\mathrm{N} 37^{\circ} 15.2^{\prime}, \mathrm{E} 137^{\circ} 14.0^{\prime}\right)$ で白山丸の $\mathrm{MH}$ 船上灯を全灯点灯し，船首甲板および船尾甲板中央付近 の右舷船縁 2 力所から舷外方向に $0 \cdot 5 \cdot 10 \cdot 20 \cdot 30 ・$ $40 \mathrm{~m}$ の位置に船外機船を定位させ，船外機船からアレ ック電子株式会社製の記録式分光照度計 (AL8W-CMP) を受光面を上にして深度 $50 \mathrm{~m}$ まで垂下し，下方向照度 を測定した。白山丸と船外機船の距離は，両船をロープ で繋ぎ，その長さで調節した。照度計だけでは深度が測 定できないので，同社製の記録式深度計（ATD-HR） と照度計を束ねて垂下し，データを読久出した後に時間 を基準にして照度と深度のデータセットを作成した。同 日にはロープを用いて姿勢を調整した LED 水中灯を深 度 $100 \mathrm{~m}$ に垂下し，受光面を下にした照度計を電源 ケーブル沿いに降下することで水中灯周囲の角度別距離 別の照度分布を測定しょうとした。しかし，水中灯と照 度計の位置関係が安定しないため良好なデータは得られ なかった。そこで, 石川県水産総合センタ一飼育棟内で 以下に述べる測定装置を用いて水中灯周囲の照度分布を 調べた。

測定装置は Fig. 2 に示したとおりである。直径 140 $\mathrm{cm}$ の透明ポリカーボネート樹脂製円形水槽の中心に 


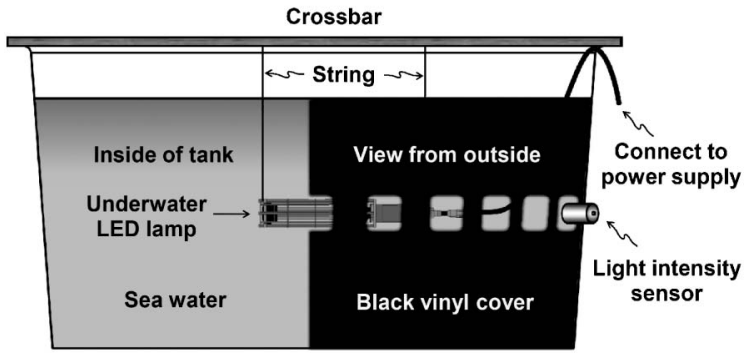

Fig. 2 Schematic diagram of tank used to measure light intensity distribution of underwater LED lamp.

LED 水中灯を横向きに懸架し, 水槽内を海水で満た し, 水槽の壁面と底面, 並びに水面の全てに黒色のビ ニールフィルムを空気が入らないように張り付けた。そ して, 水中灯の全周 24 方向の照度を測定するための空 として水槽側面のビニールフィルムに 24 カ所「コ」の 字型の切れ目を入れ, 照度測定時に 1 力所ずつ開閉で きるようにした。この状態で水中灯を点灯して内部を目 視で観察し, 壁面や水面での光の反射がほとんど無いこ とを確認した。2008 年 11 月 $14 \sim 18$ 日の夜間に室内照 明を消灯したうえで水中灯を点灯し, 測定空に照度計の 受光面を押し当てて照度を測定した。この方法では水槽 壁面での光吸収の影響があるため, 別途, 壁面の吸収率 を測定して計算により壁面の影響を除去した。この照度 を初期值とし，その光が各方向に拡散と消散により減衰 しながら広がるとして ${ }^{11)}$ 水中灯周囲の距離別の照度を 計算により求めた。

本調査に用いた照度計は 8 種類のバンドパスフィル ターで分光した光の強度をフォトダイオードで測定する 構造であり, カタログデータではフィルターの中心波長 は $398 ・ 437 ・ 488 ・ 542 ・ 589 ・ 629 ・ 678 ・ 707 \mathrm{~nm}$, 半 值全幅は概ね $60 \sim 80 \mathrm{~nm}$ であった。この照度計に関し てメーカーに確認したところ, 波長帯間でエネルギー量 や光量子数に基づいた調整はされて抢らず，得られる值 は個々のフォトダイオードの電流の相対值であり, 異な る波長帯の值は相互に比較できないことが分かった。し かし, 同一波長帯の値については, その波長帯の放射照 度の指標値とみなすことができる。スルメイカは視物質 を 1 種類しか持っておらず，その吸収極大波長は 482 $\mathrm{nm}$ である。 ${ }^{12,13)}$ 照度計のバンドパスフィルターのうち 中心波長 $488 \mathrm{~nm}$ のフィルター特性がスルメイカ視物質 の吸収曲線に類似することから, ${ }^{14)}$ 本研究ではこの波長 帯の值をスルメイカに対する照度の指標值とした。

音響機器による行動観察 白山丸には古野電気株式会 社製のカラー魚群探知機 FCV-1200L（周波数：107 $\mathrm{kHz}$ ) とスキャニングソナー CSH-81（周波数 : $81 \mathrm{kHz}$ ) が装備されており, 両機器のアナログ RGB コンポーネ ント映像信号を動画ファイルに変換してハードディスク
に記録した。操業中にCPUEが高まり, 船底下にスル メイカが集群した段階で水中灯を点灯・消灯し, その時 のスルメイカの行動を魚群探知機とソナーを用いて観察 した。釣機稼働中には上下する擬䬣針や錘が魚群探知機 に映り，行動観察が困難になるので調査時には釣具ライ ンを巻き上げて釣機を停止した。

計量魚群探知機による分布密度測定 LED 水中灯点 灯前後のスルメイカの分布密度を計量魚群探知機で測定 した。計量魚群探知機には SIMRAD 社製 EK60 システ ムを用い, 送受波器には周波数 $70 \mathrm{kHz}$ の同社製 $\mathrm{ES} 70-$ 11 を用いた。調查時には送受波器をステンレス製のフ レーム $(54 \times 54 \times 54 \mathrm{~cm})$ に固定し, 白山丸のファンネ ル横の左䑪側ダビットから音響ビームが鉛直下向きにな るように深度 $5 \mathrm{~m}$ に垂下した。使用した計量魚群探知 機はスプリットビーム式であり, in situ法によりスルメ イカのターゲットストレングス（TS）を測定した。 2009 年 8 9 月の調查で測定した TS は $-42.5 \sim-44.4$ $\mathrm{dB}$ であった。本調查の漁獲物サイズに近い外套長 23 $\mathrm{cm}$ 前後の個体では $-37.2 \sim-48.2 \mathrm{~dB}$ （周波数 : $28.5 \sim$ $120 \mathrm{kHz})$ の TS が報告されており, 15-20) 本調查で測定 したTS はこの範囲にあった。音響データは Myriax 社 製のソフトウェア Echoview で解析した。調査期間の日 中にはタングステンカーバイド製標準球を用いて送受波 感度を校正した。

\section{結果}

LED 水中灯の発光特性 円形水槽を用いて測定した LED 水中灯の配光曲線は Fig. 3 亿示したと抢りであ る。灯具を直立させた垂下姿勢では照度は水平方向に最 も強く, 鉛直方向に最も弱かった。この水中灯には LED が円筒状に配置されているため, 立体的にはドー ナツ型の配光であることが分かった。水中灯に実装され た LED の発光色は青緑色であり, カタログデータでは ピーク波長は $499 \mathrm{~nm}$ 前後, 半值全幅は概ね $30 \mathrm{~nm}$ であ った。このため $488 \mathrm{~nm}$ と $542 \mathrm{~nm}$ の波長帯の照度が卓 越し, それ以外の波長帯では光はほとんど検出されなか った。LED 水中灯の明るさ (光量) は操作盤により 0 〜 100\% (最大值) の範囲で調節可能であった。そこで, 調節值をかえて照度を測定したところ, 調節值に対して 照度はS 字型の曲線となり (Fig. 4), 調節值 100\%の 照度を $100 \%$ とすると, 調節值 $40 \%$ 以下では照度の相 対値は調節值より低かった。

海中分光照度分布 $\mathrm{MH}$ 船上灯点灯時に船首甲板打 よび船尾甲板の中央付近の 2 ヶ所から舷外方向に向か って測定した $488 \mathrm{~nm}$ 帯の照度について, 距離別・深度 別に平均值を求めた（Fig. 5)。照度は船体中央から 5 $10 \mathrm{~m}$ 付近の表層で最も高く, それよりも舷外方向には 比較的緩やかに, 船底下方向には急激に低下し, 船底下 


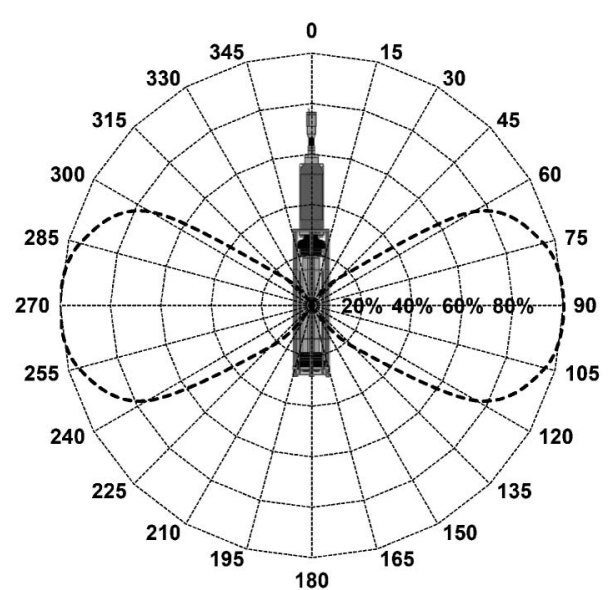

Fig. 3 Light intensity distribution of underwater LED lamp. Light intensity was measured in the $488 \mathrm{~nm}$ band.

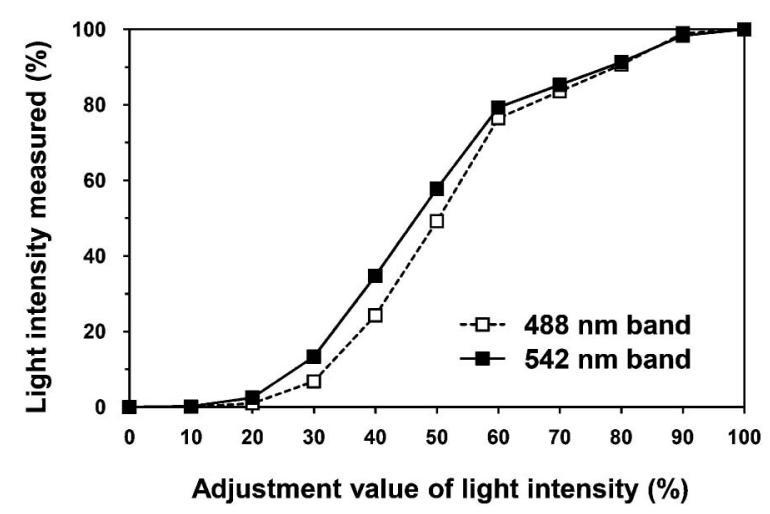

Fig. 4 Relationship between adjustment value of light intensity of underwater LED lamp and relative value of light intensity measured.

に扇状の陰影部が形成されていることが確認できた。こ の実測結果に LED 水中灯周囲の照度の計算値を加算し たものを水中灯点灯時の照度分布とした。計算により照 度を求める場合, 消散係数の設定しだいで光の広がりが 変化する。本報では 2005 年 11 月に大和堆付近で実施 したイカ釣り調査航海時に太陽光を光源とし, 本調査と 同一の照度計を用いて 1 日 1 回計 8 回測定した深度 50 $\mathrm{m}$ 以浅の $488 \mathrm{~nm}$ 帯の消散係数の平均値 (0.083) を計 算に用いた。深度 $20 \mathrm{~m}$ 抢よび $50 \mathrm{~m}$ で LED 水中灯 1 灯を光量調節值 $100 \%$ で点灯したときの照度分布を計 算したところ（Fig. 5), 水中灯の光によって船底下陰 影部が部分的に消失・分断されるため, 水中灯の垂下深 度が深くなるほど陰影部が押し下げられ，扇状であった 陰影部の形状も損なわれてしまうことが分かった。

釣獲試験 2009 年 10 月 16 日と 20 日の操業時にそ れぞれ MH 水中灯と LED 水中灯を深度 $50 \mathrm{~m}$ に垂下し， 1 時間単位で点灯（LED 水中灯の光量調節値は $100 \%$
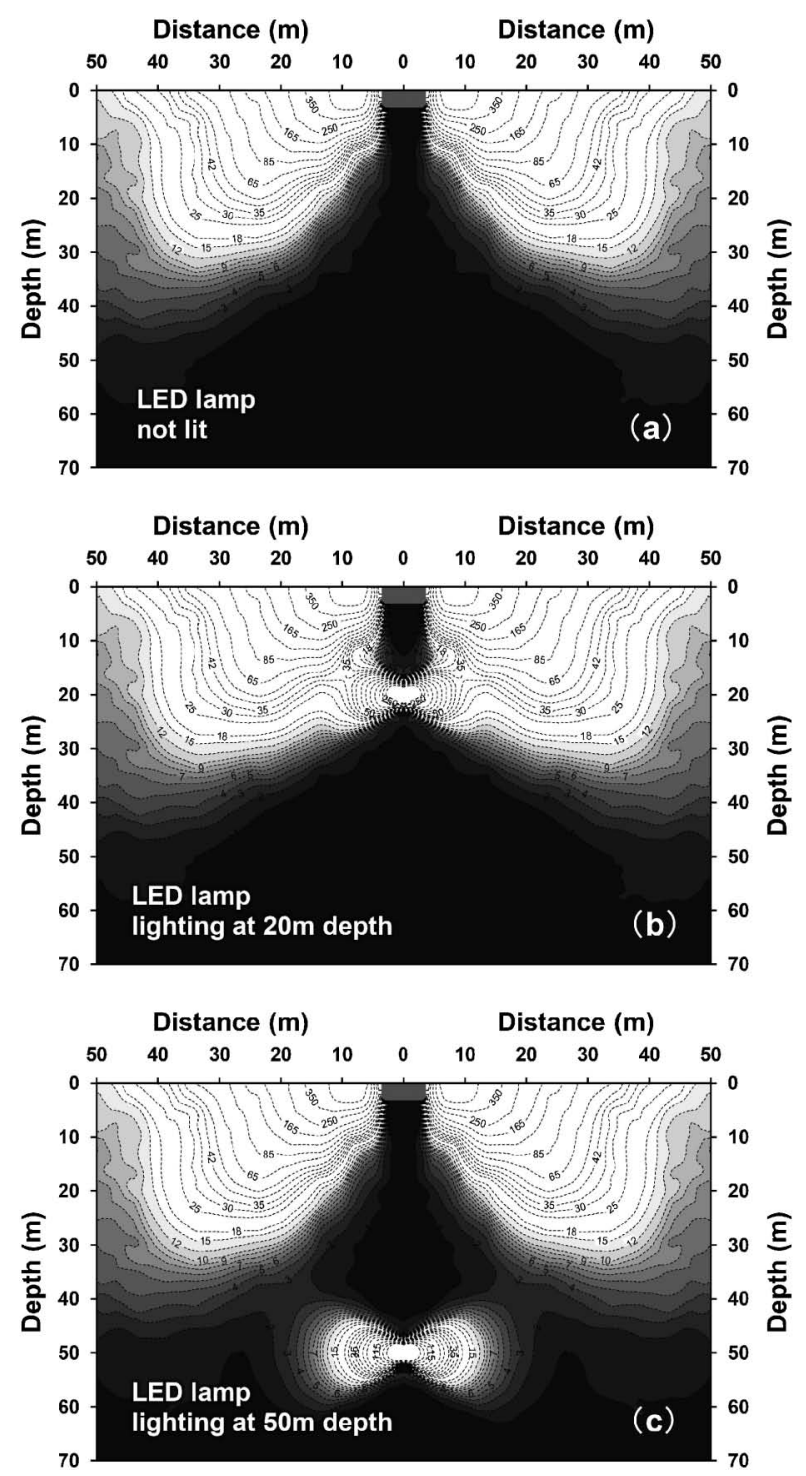

Fig. 5 Vertical distribution of underwater light intensity measured in the $488 \mathrm{~nm}$ band in the port-starboard direction of $\mathrm{R} / \mathrm{V}$ Hakusan-Maru. Numbers in the figure are electric output value of light intensity sensor (AL8W-CMP, ALEC Electronics Co., Ltd.). a: All shipboard MH lamps were lit. b, c: All shipboard $\mathrm{MH}$ lamps and underwater LED lamp were lit.

とした）と消灯を繰り返した。両操業の 1 時間毎の CPUEについて消灯状態から点灯した場合と点灯状態 から消灯した場合に分けて結果を整理したところ， LED 水中灯々 MH 水中灯のいずれでも CPUE は水中 灯を点灯すると有意に低下し (Wilcoxon の符号付順位 和検定, $p<0.01)$, 消灯すると有意 $(p<0.01)$ に上昇 した (Fig. 6)。

魚群探知機による行動観察 操業中に船底下にスルメ イカが集群した段階で水中灯を点灯・消灯し，その時の 魚群探知機反応の变化を観察した。釣機稼働中には擬餌 

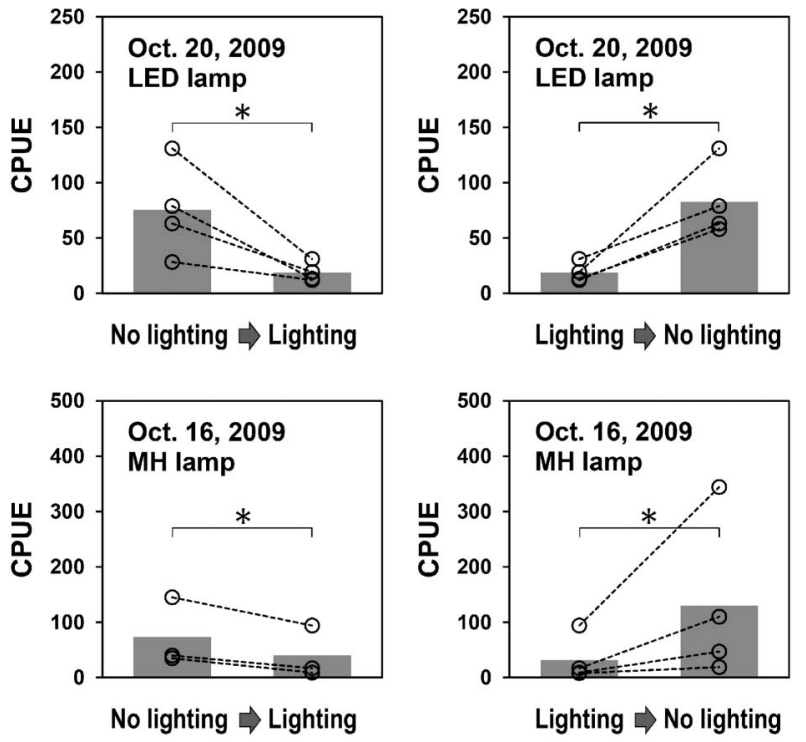

Fig. 6 Changes in catch per unit effort (CPUE) with lighting and no lighting of underwater LED and $\mathrm{MH}$ lamps. Underwater lamps were set at $50 \mathrm{~m}$ depth. CPUE is expressed as the number of squid caught per machine-hour. Each bar indicates mean CPUE. Asterisk indicates significant difference between groups ( $p$ $<0.01$, Wilcoxon signed-rank test).

針や錘の反応が強いことに加えて, スルメイカの行動が 活発であるため行動観察が困難である。しかし，釣機を 停止するとスルメイカの行動が鎮静化し, 魚群探知機に はスルメイカは層状反応として映り, 観察しやすい状態 になることがこれまでの調査で分かっていた。そこで本 調查では釣機を停止して反応が安定するのを待ってから 観察を開始した。2008 年 9 月 20 日と 2009 年 8 月 23 日の水中灯消灯時にはそれぞれ深度 $20 \sim 80 \mathrm{~m}$ と深度 20〜50 m に層状の反応がみられた（Fig. 7)。船首から 深度 $50 \mathrm{~m}$ に垂下した LED 水中灯を光量調節值 $100 \%$ で点灯したところ，水中灯の垂下深度付近より上層の反 応が数秒のうちに消失した。水中灯点灯中には, この深 度層に反応が現れることはほとんどなかったが，消灯す ると 1 分以内に水中灯上り上層に反応が現れて水中灯 点灯前の状態に戻った。このような反応の変化は LED 水中灯に特有の現象である可能性もあるため, 2009 年 10 月 17 日に $\mathrm{MH}$ 水中灯を船尾から深度 $50 \mathrm{~m}$ に垂下し て同様の実験を行った。水中灯消灯時には深度 30〜100 $\mathrm{m}$ 付近に反応がみられ (Fig. 7), 点灯後 4 分程度して から深度 $50 \mathrm{~m}$ 以浅の反応が消失する様子が観察された。 LED 水中灯に比べて MH 水中灯では反応が変化するま でに時間がかかったが，これは点灯してから所定の明る さに達するまでに時間を要する $\mathrm{MH}$ 灯の特性によるも のと考えられた。その後, $\mathrm{MH}$ 水中灯を消灯すると再 び深度 $50 \mathrm{~m}$ 以浅に反応が現れた。従って, LED 水中
灯と $\mathrm{MH}$ 水中灯のいずれでも点灯・消灯にともなう反 応の変化は同様であると判断した。

水中灯を点灯すると水中灯の垂下深度付近より上層の 反応が消失することから, 水中灯の垂下深度によって反 応の変化が異なる可能性が考えられた。そこで，2008 年 9 月 20 日には LED 水中灯の垂下深度を 20 および $80 \mathrm{~m}$ にした実験も行った（Fig. 8)。垂下深度が $20 \mathrm{~m}$ の場合には水中灯点灯直後に深度 $30 \mathrm{~m}$ 以浅の反応が消 失しただけで，それ以深の反応に変化は認められなかっ た。垂下深度が $80 \mathrm{~m}$ の場合には水中灯点灯直後にほと んぞ全ての反応が消失し, その後, 深度 $30 \mathrm{~m}$ 付近から $50 \mathrm{~m}$ 付近にかけて反応が徐々に現れる様子がみられ た。このように水中灯の垂下深度が深いほど水中灯点灯 直後の反応の消失は顕著であった。2009年 8 月 22 日 には LED 水中灯の光量調節值を変えて反応の変化を観 察した。その結果, 調節値を $10 \%$ から $30 \%$ に上げた 段階で水中灯より上層の反応が消失し, 水中灯が明るい ほど反応の消失は顕著であることが分かった。

ソナーによる行動観察 2008 年 9 月 20 日にLED 水 中灯を船首から深度 20,50 および $80 \mathrm{~m}$ に垂下して光量 調節值 $100 \%$ で点灯し, ソナー画像の変化を観察した (Fig. 9)。ソナーのレンジは $100 \mathrm{~m}$, 俯角は $60^{\circ}$ に設定 した。深度 $20 \mathrm{~m}$ で点灯した場合には消灯時に比べて船 首側の船体に近い部分の反応がやや弱まったものの大き な変化はなかった。しかし, 深度 $50 \mathrm{~m}$ で点灯したとき は, 概补半径 $30 \mathrm{~m}$ の範囲・深度 $50 \mathrm{~m}$ 以浅の反応が消 失し, 深度 $80 \mathrm{~m}$ で点灯したときに至っては, 概ね半径 $50 \mathrm{~m}$ の範囲・深度 $87 \mathrm{~m}$ 以浅にわたって反応が消失し た。このように水中灯の垂下深度が深いほど反応の消失 する範囲は広いことが明らかになった。

2009 年 8 月 22 日には LED 水中灯を船首から深度 50 $\mathrm{m}$ に垂下し, 光量調節值を変えて反応の変化を観察し た (Fig. 10)。調節值 10\% で点灯したときの反応は消 灯時と大差なかった。しかし, 調節值 30\%で点灯する と概补半径 $30 \mathrm{~m}$ の範囲・深度 $50 \mathrm{~m}$ 以浅の反応が消失 し, 調節值 $100 \%$ では概ね半径 $35 \mathrm{~m}$ の範囲・深度 60 $\mathrm{m}$ 以浅の反応が消失し, 水中灯が明るいほど反応の消 失する範囲は広いことが明らかになった。

計量魚群探知機による分布密度測定 2009 年 8 月 22 日と 23 日にLED 水中灯点灯前後のスルメイカの分布 密度の変化を調べた（Fig. 11）。通常の魚群探知機で観 察されたのと同様, 計量魚群探知機でも LED 水中灯消 灯時には層状の反応が見られ, 水中灯を点灯すると水中 灯の垂下深度付近よりも上層の反応が消失することが確 認された。しかし, 計量魚群探知機では反応が消失する までに $30 \sim 40$ 秒を要し, 水中灯点灯後 3 分程度すると 水中灯より上層の反応がやや増加した。通常の魚群探知 機に比べて計量魚群探知機のほうが送受波器と水中灯の 

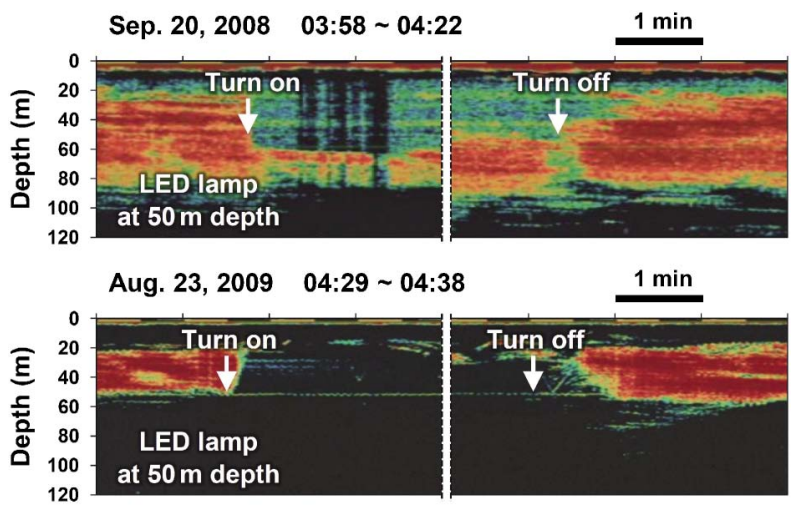

Oct. 17, 2009 04:08 04:57
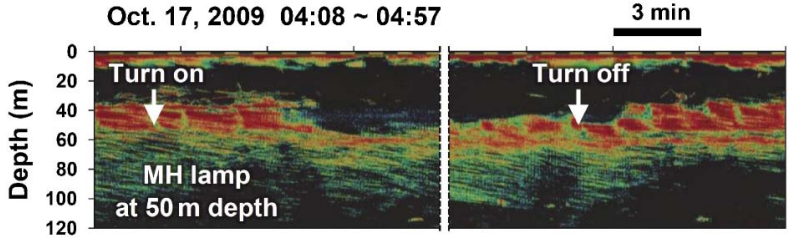

Fig. 7 Changes in echogram of squid after turning on/off underwater LED and $\mathrm{MH}$ lamps. Shipboard $\mathrm{MH}$ lamps were continuously lit. Jigging machines were stopped during the acoustic observation.
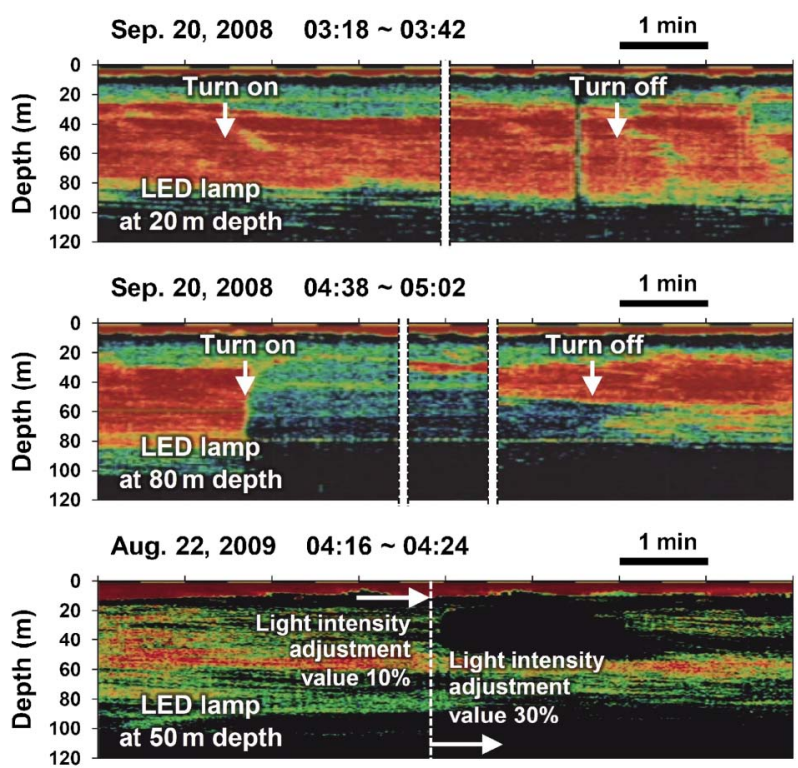

Fig. 8 Changes in echogram of squid after turning on/off the underwater LED lamp and adjusting light intensity of the underwater LED lamp. Shipboard MH lamps were continuously lit. Jigging machines were stopped during the acoustic observation.

距離がより離れていたため, 計量魚群探知機では反応が 変化するまでに時間を要したと考えられた。図中の枠で 囲んだ部分について，水中灯点灯前後の $1 \mathrm{~m}^{3}$ 当たりの スルメイカの尾数を求めたところ，8月 22 日の調査で は点灯前 : 0.042 尾, 点灯後 : 0.000 尾, 8 月 23 日の調 查では点灯前 : 0.412 尾, 点灯後 : 0.000 尾であった。
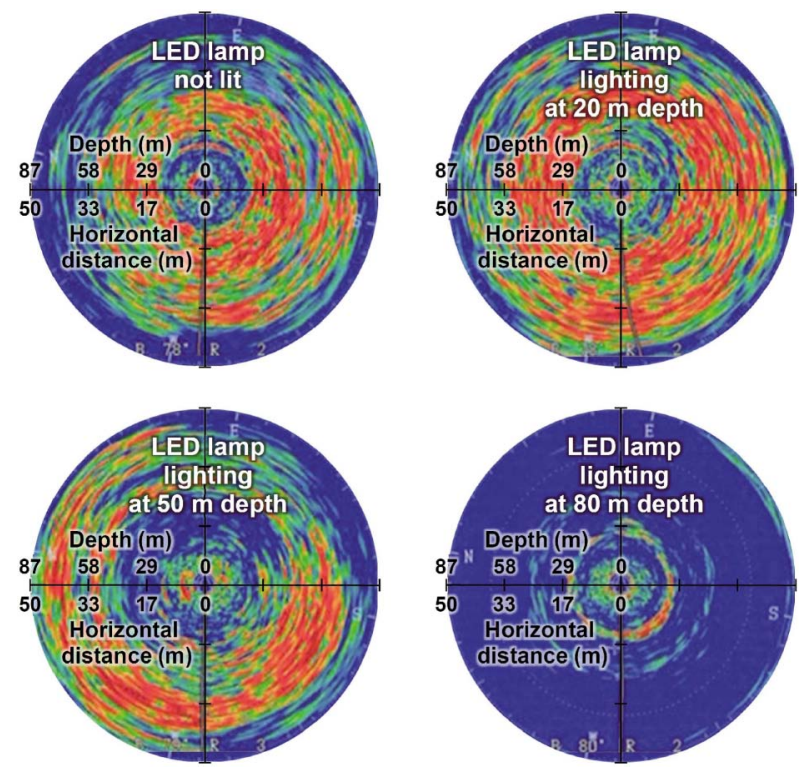

Fig. 9 Effect of setting depth of the underwater LED lamp on the sonar image of squid. Range and tilt angle of sonar were set to $100 \mathrm{~m}$ and 60 degrees, respectively. The observation was conducted from 03:14 to 04:40 Sep. 20, 2008.
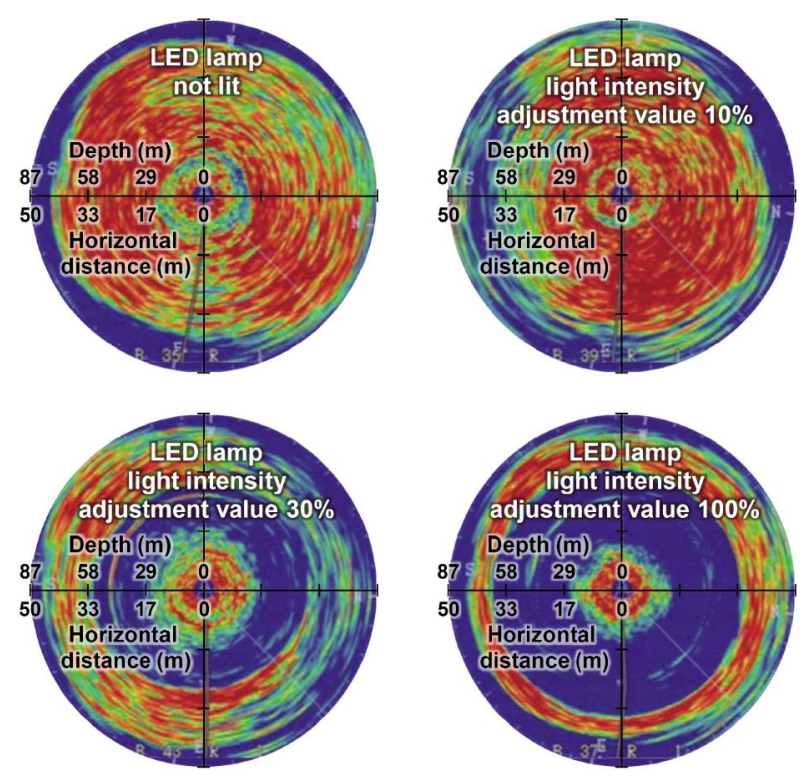

Fig. 10 Effect of light intensity of the underwater LED lamp on the sonar image of squid. Range and tilt angle of sonar were set to $100 \mathrm{~m}$ and 60 degrees, respectively. The observation was conducted from 03:10 to 04:11 Aug. 22, 2009.

考察

スルメイカを対象としたイカ釣り操業では船上灯光に より形成される船底下の陰影部が重要であることが以前 から指摘されている。船上灯の出力が数キロワット程度 

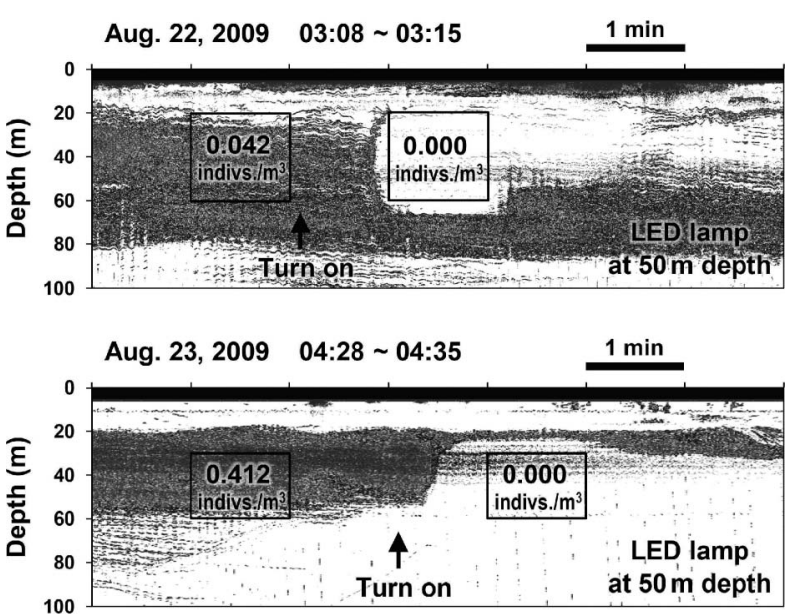

Fig. 11 Changes in echogram of quantitative echosounder (split-beam SIMRAD EK60 system) after turning on the underwater LED lamp. Density of the squid was calculated within the area enclosed with line.

であった 1950 年代から 1960 年代には既にスルメイカ は光の直射域を避けて船底下陰影部によく集まるとされ て抢り, 光の直射域と船縁の影の境界付近から船体寄り の海面に釣具ラインを下ろすと良く釣れ，光が直射する 海面に釣具ラインを下ろした場合には釣獲尾数が著しく 少なかったことが報告されている。帛 船上灯の出力が大 幅に増大した現在，大光量化によって釣獲深度は深くな っているが, 1) それでも漁業者の多くが船底下陰影部の 重要性を経験的に認め, 船上灯の配置や釣具ラインの降 下位置に注意を払っている。このようなことが以前から 認識されていたにも関わらず，海中照度との関連でスル メイカの分布が調べられたのは比較的最近のことである。

Arakawa et al. ${ }^{9}$ はスルメイカの分布をソナーで調べて 分光放射照度分布と比較し，スルメイカの分布の䑨外方 向断面は三角形であり，その形状は照度分布（陰影部） に対応していることを明らかにした。さらに，Inada ${ }^{10)}$ は網膜の黑色色素の移動からスルメイカの明暗環境に対 する順応状態を調べ，船上灯光の下で釣獲した個体のほ とんぞが暗順応状態であったことから，スルメイカは視 覚機能の面でも陰影部の低照度環境で擬餌針を捕捉する のに適した状態であることを報告している。しかし，船 上灯光により作り出される海面下の光環境がスルメイカ の行動や釣獲にどのように作用しているのかという行動 制御機能についてはあまり分かっていない。このことを 明らかにするには，海面下の光環境を意図的に変えてス ルメイカの行動を観察する能動的実験が必要である。

以上の理由から, 本研究では船上灯による操業時にス ルメイカが集群した段階で船底下に垂下した LED 水中 灯を点灯・消灯し, このときのスルメイカの行動を魚群 探知機とソナーで観察した。音響機器で行動を観察する
には，その反応がスルメイカであることを確認する必要 がある。そこで水中灯操作前後の音響反応と釣獲成績の 变化を比較した。水中灯を点灯すると魚群探知機やソ ナーの反応が消失する現象がみられ，このような場合に は CPUE も大きく低下した。さらにLED 水中灯の点灯 にともなう音響反応の消失は水中灯を操作してから数秒 程度で確認でき，釣獲尾数の減少も目視で明瞭に分かる ほど顕著かつ速やかであった。従って, 魚群探知機とソ ナーによって捉えられた反応はスルメイカであると判断 できる。

LED 水中灯を明るく点灯したときほどスルメイカの 反応の消失が顕著であったことから, スルメイカには明 るい環境を避ける性質があり, 船底下陰影部はスルメイ カの集群に不可欠の要素であることは明らかである。水 中灯点灯時には水中灯の垂下深度付近上り上層に分布す るスルメイカが選択的に逃避することが魚群探知機とソ ナーによる観察で明らかとなり, 計量魚群探知機による 調査でも水中灯の垂下深度付近より上層にはスルメイカ はほとんど分布しないことが確認された。この結果から 水中灯の垂下深度とスルメイカの逃避行動の間に密接な 関係があることが予想されたため, LED 水中灯の垂下 深度を変えて行動を観察した。その結果, 水中灯の垂下 深度が深いほど船底下陰影部からの逃避は顕著であり, 水中灯点灯中にはスルメイカは水中灯より深いところに 広く分布することが分かった。一方, 照度分布の測定結 果から, 水中灯を点灯すると船上灯によって形成された 扇状の陰影部が部分的に消失して分断されるため, 水中 灯の垂下深度を深くするほど陰影部は押し下げられ，陰 影部の形状も損なわれてしまうことが分かった。水中灯 点灯時にはこのような照度分布になるため, スルメイカ は水中灯より深いところに広く分布するようになったと 考えられる。さらに水中灯を点灯した状態から消灯して 船底下陰影部を出現させたところ, 水中灯よりも深いと ころに広く分布していたスルメイカの一部が陰影部に浮 上・集群し, 釣獲尾数も急増することが確認された。こ の結果は, 船上灯光によって形成された船底下陰影部に は船体周囲に集めたスルメイカを船底下の釣獲しやすい 位置に誘導・集約して，釣獲に結び付ける機能があるこ とを示している。

本報では海中照度分布の変化に対するスルメイカの行 動から船上灯光の機能を考察した。ここで再度, 水中灯 光とスルメイカの行動に注目すると, LED 水中灯の配 光は上下対称であったが，点灯時には水中灯の垂下深度 付近より上層に分布するスルメイカが選択的に逃避して おり, 海底方向への光より海面方向への光がより強い威 嚇刺激として作用した可能性がある。つまり, 灯光に対 するスルメイカの行動は，照度のような明るさ以外に， 光源との位置関係や光の照射方向といった空間的要素に 
も影響を受けていることが考えられる。今後, これらの 要素を考慮した実験を行い, 灯光の機能について検証を 重㸚る必要がある。

\section{謝辞}

本調査に協力いただいた漁業調查指導船白山丸の乗組 員に深く感謝する。本研究の一部は, 平成 20 年度新た な農林水産政策を推進する実用技術開発事業「LED 漁 灯と超音波測器によるイカ群の行動制御と釣獲技術の構 築（課題番号：2055）」, 並びに平成 21 年度新たな農林 水産政策を推進する実用技術開発事業「イ力釣り漁業に おける LED 漁灯の応用による効率的生産技術の開発 (課題番号 : 21059)」により実施した。ここに記して関 係各位に感謝の意を表する。

\section{文献}

1）稲田博史，小倉通男. イカ釣り漁業における集魚灯の変 化. 東京水産大学論集 1988; 24: 189-207.

2）荒川久幸. 集魚灯技術.「スルメイカの世界一資源・漁業 - 利用一」(有元貴文, 稲田博史編) 成山堂書店, 東京. 2003; 203-221.

3）四方崇文. 平成 18 年度日本海漁業操業効率化支援事業・ 漁場形成状況等調査事業青色発光ダイオード実証化試験 報告書. 石川県水産総合センター, 能登. 2007.

4）平成 $16 \sim 18$ 年度青色発光ダイオード集魚灯によるイカ つり漁業革命事業に関する報告書. 社マリノフォーラム 21 海域総合開発研究会青色発光ダイオード集魚灯による イカつり漁業革命事業グループ, 東京. 2005 2007.

5）平成 $18 \sim 21$ 年度省エネルギー技術導入促進事業報告書. 社海洋水産システム協会, 東京. 2007 2010.

6）水産業に打眇エネルギー対策と合理的なエネルギー 消費の在り方について. 独水産総合研究センター水産業 エネルギー技術研究会, 東京. 2009 .

7) 藤原里美, 佐野栄作, 臺田 望. 船上漁灯々水中漁灯. 「漁灯を活かす技術・制度の再構築へ」（稲田博史，有元 貴文, 長嶋徳雄, 飯田浩二編) 恒星社厚生閣, 東京. 2010; 72-91.
8）小倉通男, 名角辰郎. イカ釣り漁業と火光. 日水誌 1972; 38: 881-889.

9) Arakawa H, Choi S, Arimoto T, Nakamura Y. Relationship between underwater irradiance and distribution of Japanese common squid under fishing lights of a squid jigging boat. Fish. Sci. 1998; 64: 553-557.

10) Inada $H$. Retinomotor response and retinal adaptation of Japanese common squid Todarodes pacificus at capture with jigs. Fish. Sci. 1996; 62: 663-669.

11）森川由隆, 柏 俊行. 漁灯による海中光の特性とその測 定.「漁灯を活かす技術・制度の再構築へ」（稲田博史， 有元貴文, 長嶋徳雄, 飯田浩二編) 恒星社厚生閣, 東京. 2010; 40-56.

12）原 富之. 頭足類網膜の感光性色素. 「現代動物学の課題 3 光感覚」(日本動物学会編) 学会出版センター, 東京. 1986; 53-88.

13）清道正嗣, 鬼頭勇次. ホタルイカの眼. 「ホタルイカの素 顔」（奥谷喬司編）東海大学出版会, 東京. 2000; 85134.

14）四方崇文. 平成 17 年度日本海漁業操業効率化支援事業 ・漁場形成状況等調查事業青色発光ダイオード実証化試 験報告書. 石川県水産総合センター, 能登. 2006.

15) Arnaya I, Sano N. Studies on acoustic target strength of squid V, Effect of swimming on target strength of squid. Bull. Fac. Fish. Hokkaido Univ. 1990; 41: 18-31.

16) Arnaya I, Sano N, Iida K. Studies on acoustic target strength of squid I, Intensity and energy target strengths. Bull. Fac. Fish. Hokkaido Univ. 1988; 39: 187-200.

17) Arnaya I, Sano N, Iida K. Studies on acoustic target strength of squid IV, Measurement of the mean target strength of relatively large-sized live squid. Bull. Fac. Fish. Hokkaido Univ. 1989; 40: 169-181.

18）川端 淳. スルメイカのターゲットストレングスの測 定. 東北水研研報 1999; 61: 29-40.

19）川端 淳. 計量魚探を使った 1996〜2001 年の三陸北部 海域に抢けるスルメイカの現存量推定. 平成 14 年度イ 力類資源研究会議報告, 北海道区水産研究所, 釧路. 2003; 77-82.

20) Kang D, Iida K, Mukai T, Kim J. Density and sound speed contrasts of the Japanese common squid Todarodes pacificus and their influence on acoustic target strength. Fish. Sci. 2006; 72: 728-736. 